\title{
SOME OSCILLATION RESULTS FOR SECOND ORDER NEUTRAL TYPE DIFFERENCE EQUATIONS
}

\author{
E. THANDAPANI AND V. BALASUBRAMANIAN
}

\begin{abstract}
This paper is concerned with the oscillatory behavior of second order neutral difference equations. Four oscillation theorems for such equations are established and examples are given to illustrate the results.
\end{abstract}

Mathematics subject classification (2010): 39A11.

Keywords and phrases: second order, neutral type difference equation, oscillation.

\section{REFERENCES}

[1] R.P. Agarwal, Difference Equations and Inequalities, Second Edition, Marcel Dekker, New York, 2000.

[2] R.P. Agarwal, M. Bohner S.R. Grace, and D. O'Regan, Discrete Oscillation Theory, Hindawi Publ. Corp., New York, 2005.

[3] J. Jiang, Oscillation of second order nonlinear neutral delay difference equations, Appl. Math. Comp., 146 (2003), 791-801, doi:10.1016/S0096-3003(02)00631-8.

[4] R. Koplatadze, G. Krinikadze and I.P. Stavroulakis, Oscillation of second order linear difference equations with deviating arguments, Adv. Math. Sci. Appl., 12, (1) (2002), 217-226.

[5] H.J. Li AND C.C. YeH, Oscillation criteria for second order neutral difference equations, Comp. Math. Appl., 36 (1998), 123-132, doi:10.1016/S0898-1221(98)80015-1.

[6] J. Lu, Oscillation criteria for second order neutral difference equations, Ann. Diff. Eqns., 14 (1998), 262-266.

[7] Y.G. SUN AND S.H. SAKER, Oscillation for second order nonlinear neutral delay difference equations, Appl. Math. Comput., 163 (2005), 909-918, doi:10.1016/j.amc.2004.04.017.

[8] E. Thandapani, Z. LiU, R. ARUl AND P.S. Raja, Oscillation and asymptotic behavior of second order difference equations with nonlinear neutral terms, Appl. Math. E-Notes, 4 (2004), 59-67.

[9] E. Thandapani AND K. Mahalingam, Oscillation and nonoscillation of second order neutral delay difference equations, Czech. Math.J., 53, (128) (2003), 935-947, doi:10.1023/B:CMAJ.0000024532.03496.b2.

[10] E. Thandapani And K. Mahalingam, Necessary and sufficient conditions for oscillation of second order neutral delay difference equations, Tamkang J. Math., 34, (2) (2003), 137-145.

[11] E. ThANDAPANI AND P. MOHANKUMAR, Oscillation and nonoscillation of nonlinear neutral delay difference equations, Tamkang J.Math., 38, (4) (2007), 323-333.

[12] E. Thandapani, S. Pandian AND R.K. Balasubramaniam, Oscillation of solutions of nonlinear neutral difference equations with nonlinear neutral term, Far-East J. Appl. Math., 15, (1) (2004), 47-62.

[13] E. Thandapani And S. Selvarangam, Oscillation theorems of second order quasilinear neutral difference equations, J. Math. Comput. Sci., 2, (4) (2012), 866-879.

[14] E. Thandapani, P. Sundaram, J.R. GRAeF, AND P.W. SPIKES, Asymptotic properties of solutions of nonlinear second order neutral delay difference equations, Dyn. Sys. Appl., 4 (1995), 125-136.

[15] D.M.WANG AND Z.T.XU, Oscillation of second order quasilinear neutral delay difference equations, Acta Math. Appl. Sinica, 27, (1) (2011), 93-104, doi:10.1007/s10255-011-0043-4. 